\title{
Three Norwegian Experiences in Post- Revolutionary Mexico: Per Imerslund, Halfdan Jebe and Ola Apenes
}

\author{
Ricardo Pérez Montfort
}

Introduction

At the beginning of the 1940s, Mexico's Migration Service had in its registry of foreigners about 120 Norwegians. Most arrived in the country in the early $1920 \mathrm{~s}$ and a smaller percentage did so during the following decade. ${ }^{1}$ The 1930 census recorded only seventy-one nationwide, so generally speaking, in a country with approximately 16.5 million inhabitants, the number of Norwegian immigrants was truly insignificant. ${ }^{2}$ Indeed, it appears that Mexico was rarely considered as a destination for Norwegians in the early twentieth century, if we compare it with the United States of America or other countries on the American continent, such as Argentina or Chile.

The three Norwegians described in this chapter were very different individuals who had very diverse experiences and adventures in a country that was emerging from a revolution and entering its first stage of modernization in the twentieth century. For Mexico, the post-revolutionary years from 1920 to 1940 represented a complex process of establishing peace and entering into a world involved in a debate over socialist and capitalist currents, each with particular hints of pure nationalism. Between outbreaks of violence and recognition of a national art and a vigorous past, which was no less exotic, modern, and eager for discoveries, the three Norwegians knew how to assimilate effectively during those twenty years. Despite their dissimilarities, their Mexican experience

1 I owe this information to Delia Salazar, who was kind enough to send me a list of Norwegian citizens found in the National Registry of Foreigners of the Ministry of the Interior 1917-47 kept in the National Archives, and to the detailed work of Steinar Sæther, coordinator of the research project "Desired Immigrants - Frustrated Adventurers? Norwegians in Latin America (1820-1940)," who also provided me with valuable information on the other Norwegians mentioned in these pages. I would also like to thank Dr. John Dagfinn Bergsagel for his accurate suggestions and corrections on Halfdan Jebe's story.

2 Delia Salazar Anaya, La población extranjera en México (1895-199o): Un recuento con base en los Censos Generales de Población (México: INAH 1996), 294.

(C) KONINKLIJKE BRILL NV, LEIDEN, 2016 | DOI 10.1163/9789004307391_009 
was decisive in the paths of their lives. All three contributed to the knowledge and art of their time, although each was recognized independently since their spheres of action could not be more distant.

First, we will follow the adventures of Nils Per Imerslund, a restless young man who after visiting Mexico and publishing a pair of fictionalized autobiographical accounts, would become an important figure within Norwegian Nazism until he died during World War II. Second, we will review the life and work of musician Halfdan Jebe, who would end his long and eventful experience on Mexican soil after a troubled stay in Yucatán full of teaching and creating music. Finally, we will recount the experiences and contributions of the engineer and mathematician Ola Apenes amid the reconstruction of the Mexican past during the 1930s. Like Imerslund, Apenes died unexpectedly during World War II, although his political sympathies were clearly the opposite of his compatriot.

The regions in Mexico where the three spent their time were equally contrasting: Imerslund's experiences took place mainly in the state of Colima, in the country's midwestern region; Halfdan Jebe was active in Mérida, capital of the state of Yucatán, in the far southeast corner of the country; and Ola Apenes did his research and made his contributions in Mexico City and the surrounding area. The trio's activities were also very different, as they ranged from teaching, artistic research, and technical service to commerce, plunder, and war. Therefore, their adventures in Mexico are particularly interesting and to some degree atypical, if one thinks about migration as a phenomenon that is strictly about adventure or work.

Imerslund, Jebe, and Apenes all developed a particular interest in the exotic and mythical pre-Hispanic world. While the former saw it as a possible source of wealth and adventure, the latter two viewed it as an inspiration, and an area of knowledge and research.

Mexico - during these post-revolutionary years and in the process of modernizing - was a key influence on the lives and works of these three Norwegians.

\section{Nils Per Imerslund and His Family in Mexico}

Also called the "Aryan Idol" (Det ariske idol), Nils Per Imerslund was born on May 9, 1912, in Kristiania and died on December 7, 1943, at Aker University Hospital in Oslo. Tall, blond, and athletic, an adventurer and reputed homosexual, he was a prominent figure in the Norwegian Nazi scene shortly before and during World War II. As a promoter of certain ideas linked to ethnic purity, racial superiority, and anti-communism, he was well known from the second 
half of the 1930s as a local leader who shared many affinities with German National Socialism. While maintaining a critical look at radicalism itself and the irrationality of Nazism, especially at the end of his life, his Pan-German ideas linked him more with the populist and traditionalist justifications of nationalism prevailing in some affluent sectors of Norwegian society of his time. Supporting himself on the völkisch ideas that appealed to the popular values of his racial doctrine, he had a close relationship with Hans Solgaard Jacobsen, one of its main promoters through the Ragnarok organization and its magazine. ${ }^{3}$

Per Imerslund lived an intense life in Berlin and in nationalist circles in Norway during the 1930s. He was, however, a constant opponent of Vidkun Quisling and his party, even though their interests converged in favor of the emerging Nazism. Between 1937 and 1938, he joined the Spanish Falange army, but his participation in the Spanish Civil War seemed to be uneventful. After World War II began, he decided to fight in support of Nazism, although with a particularly critical position because of the alliance between Hitler and Stalin. Once the alliance was broken, with certain reservations against both German imperialism and the coup d'état perpetrated by Quisling in 1940, Imerslund participated in the resistance against the Soviet invasion of Finland and in the Nazi attacks against Ukraine. Shortly after, he returned to his political activities, bolstered in part by the main leaders of German National Socialism and partly by his own followers and fellow Norwegians. Wounded twice at the front, he used his recovery time to write and disseminate his Pan-German ideas in magazines and radio broadcasts. His reputation as a daring, brave, and passionate young Aryan grew exponentially - although his criticism of what was happening in Norway with Vidkun Quisling and Josef Terboven at the head led to more confrontations and misfortunes. His participation in a group that conspired against Quisling, as well as his own disillusionment with the Nazi atrocities committed in Norway as of 1941, brought him ever closer to the formation of a resistance front against those who governed his country. At the end of 1943, it appeared as though the front was now in a position to act. However, a number of complications from his injuries led to Per Imerslund's death on December 7 of that year, at the age of thirty-one.

Per's father was Thorleif Imerslund, a member of a wealthy bourgeois family from Elverum. Thorleif was a successful young businessman, but also a

3 An excellent biography of Per Imerslund can be found in Terje Emberland and Bernt Rougthvedt, Det Ariske Idol. Forfatteren, Eventyreren og nazisten Per Imerslund (Oslo: Aschehoug, 2004). The majority of the information presented here, except for that about his stay in Mexico, comes from this biography. 
gambler and a philanderer. Per's mother, Anna Maria Drogseth, was also a somewhat controversial figure with a libertine lifestyle who would have a particular influence on her two children. Per had a sister who was two years older named Eva, with whom he maintained a close, but stormy relationship. In 1920, the family moved to Germany, where Per attended the Königliche Paul-Gerhardt Schule in Lübben am Spreewald near Berlin. It was an aristocratic school that emphasized Prussian militarism and discipline, but also praised courage and adventure. During his vacations, Per returned to Norway to Elverum, to the home of his grandfather, who was also a prominent local figure. In Berlin, Per's private tutor was Hans Dietrich Disselhof, a Prussian veteran of World War I, who reportedly was his mother's lover and perhaps also his father's. The relationship between Disselhof and Per was described years later as "nicht männlich" (improper for men). ${ }^{4}$ In 1923, Thorleif's companies went bankrupt, and his failed business dealings resulted in a remarkable social decline for his family. Slowly, and with the support of his father's family, the businessman replaced part of his lost capital, and a few years later again enjoyed a certain economic boom.

In 1925, on a trip to Paris, Thorleif Imerslund met Jorge Michel, a young Mexican from a landowning family in the state of Colima who invited him to Mexico, offering him a possible answer to his continuous economic crises. Colima, the smallest state of the Mexican republic, is bordered by the Pacific coast and the states of Jalisco and Michoacán in central western Mexico. During the 1920s, the state of Colima had a population of approximately ninety thousand inhabitants. Around twenty-eight thousand people lived in the state capital of the same name. Manzanillo, the second largest city in the state, is on the coast, and at that time it was a medium-size port with just over six thousand inhabitants. ${ }^{5}$ In the state of Colima, two large rivers - the Salinas and the Coahuayana - flow down from the highlands of the Sierra Madre Occidental toward the Pacific Ocean. Passing through large ravines, one finds a tropical climate that remains that way during most of the year. The heat and humidity have made the land of Colima very fertile to this day. Grains, grass, coffee, cotton, tobacco, indigo, and palm fruits are grown there. The main exploitation on the coast was of the salt beds of Cuyutlán and San Pantaleón. In the highlands, the double cone of the so-called Fire Volcano of Colima still dominates a large part of the region. It is an active volcano, just over 3,800 meters above sea

4 Interview with Terje Emberland, September 18, 2013.

5 Jesús Galindo y Villa, Geografía de la República Mexicana (México: Sociedad de Edición y Librería Franco Americana, 1927), vol. II, 455. 
level. ${ }^{6}$ In the late nineteenth century, the railway joined Colima and Manzanillo with Guadalajara, the most important city of western Mexico. Thorleif Imerslund, led by Jorge Michel, came to this tropical corner of Mexico in 1926.

After visiting Colima and touring the Michel family's land, Jorge offered Thorleif half of a huge property in exchange for a loan, which he would pay interest on for five years, and the priority for purchase of the land once the deadline expired. They entered into a partnership agreement, which stipulated that Jorge Michel would receive from Thorleif Imerslund twenty-five thousand pesos in national gold as an investment to rehabilitate a coconut plantation near the city of Tecomán, Colima, under the responsibility of the Michel y Cia. company, newly created by the two interested parties. ${ }^{7}$ The plantation was named Las Humedades and together with two other properties named Armería and Cualta, which were added later, it comprised about thirty thousand hectares. Between 1929 and 1930, 150,000 palm trees were planted on that land, with the intention of soon increasing the number to 250,000 . Since Thorleif was a foreigner and the plantation lands extended through areas "reserved for nationals only" and even reached the coast of the Pacific Ocean, the contract signed in May 1926 had no official status. ${ }^{8}$ In subsequent years, this worried Thorleif because he never had any possession or guarantee of ownership of the acquired properties.

At the beginning of 1931, he wanted to apply for Mexican nationality - trying not to lose his rights as a Norwegian citizen - to protect his status as a property owner, probably because he felt that the Michel family would not honor its commitment. ${ }^{9}$ In fact, a year earlier, in July 1930, the governor of Colima, Laureano Cervantes, authorized the dissolution of the Michel y Cia. company, granting Thorleif Imerslund and Jorge Michel $5^{\circ}$ percent of the properties each. ${ }^{10}$ However, in August 1931, a dispute erupted between the two, a disagreement that ended in the imprisonment of Jorge Michel, who was accused of massive fraud. ${ }^{11}$ Thorleif filed a suit not only for the twenty-five thousand pesos that he had originally given to Michel at the time when they formed the

6 Servando de la Cruz Reyna, "El Volcán de Fuego de Colima," in Los volcanes de México, ed. Hugo Granados Delgado (México: UNAM, 2002), 87-97.

7 Archive of the Norwegian Foreign Ministry in Oslo (AMnrno) Koloni i Mexico og Centralamerika Journ. Nov nr. 18, 1928.

8 The Constitution of 1917 prevented foreigners from owning land and emphasized the impossibility of their purchasing land in coastal and border areas. See Constitución política de los Estados Unidos Mexicanos, comentada (México: UnAM, 1985), 74. Amnrno Koloni i Mexico og Centralamerika Journ. N + NF nr.36, October 21, 1931.

10 amnrno Koloni i Mexico og Centralamerika Journ. N + NF nr.36, 1928.

11 "Un proceso que promete ser ruidoso" in Ecos de la Costa, Colima, September 27, 1931. 
company, but he also demanded another twenty-five thousand pesos for payment of revenues and the investment in the coconut palm plantations, plus thirteen thousand in expenses for the purchase of corn, sale of pigs, machinery, and other earnings that Michel had collected since the beginning of 1929. In total, he claimed $73,35^{\circ}$ pesos. ${ }^{12}$

Even though before long he was denied an injunction, Jorge Michel was released by the attorney general of the state of Colima in November. Thorleif immediately wrote the consul of Norway in Mexico and the federal attorney general to protest and to make the chief prosecutor in the country aware of the case. He asked him to do everything possible to guarantee that justice be respected and in particular that "the defendant and the now-accused state attorney general be held accountable for their mistakes."13

In early 1932, Thorleif's situation in Colima appeared to be unresolved, but he kept fighting. He even took part in the electoral campaign of that year that ended with Salvador Saucedo being elected governor. Saucedo stood out as particularly corrupt and authoritarian, and apparently this worked in Thorleif's favor. But in this process it became clear that as a foreigner, he could expect little from the Mexican justice system. For that reason, it did not take long for Thorleif Imerslund to begin his process of naturalization. The process took several years and was not completed until $1943 .{ }^{14}$

Meanwhile, the Imerslund family, which included wife Ana Maria and children Eva and Per, along with Hans Dietrich Disselhof, had traveled several times between 1927 and 1932 from Norway to Mexico and back, with some ups and downs. Perhaps the most serious, in addition to the conflict between the Imerslund and Michel families, was the death of Per and Eva's mother. Shortly before the end of the family's first trip in 1927-28, Ana Maria suffered from food poisoning while aboard the ship during their return and died unexpectedly.

12 Amnrno Koloni i Mexico og Centralamerika Journ. N + NF nr.36, October 21, 1931.

13 Amnrno Koloni i Mexico og Centralamerika Journ. N + NF nr.36, November 9, 1931.

14 Archivo General de la Nación (AGN) (General Archive of the Nation) Ramo Gobernación: Foreign Registry: Exp. 2.361.11920. In 1936, he was still registered as a foreigner, although by then he was recognized as a landowner. Thorleif Imersland continued living in Mexico during the 1940s. He obtained his immigrant status in 1943. During the 1950s he had a farm in Colima, which he called Oslo and which mainly produced flowers and vegetables. He also had other businesses that were registered through a limited company that acted first under the name of Imerslund y Villanueva, and then as Cine-Mex de Occidente. Apparently he was co-owner of a store that purchased and sold film and electrical, photographic, and audio equipment. The last record of him in Colima in Norway's Archives is from 1957. AMNRno Koloni I Mexico og Centralamerika Exp. 2065 Loo1, Loo2 and Loo3. 
The details of her indulgent life were revealed on her deathbed and apparently the two young Imerslund children were particularly affected..$^{15}$

That trip in 1927 was the first for Per, when he was just fifteen years old. His distance from Norway seemed to increase his nationalism, as well as his view of ethnic differences. The exotic and tropical world also stimulated his adventurous spirit and his contact with nature. But this was not the only visit to Mexico that influenced him. In 1930 he returned to Colima to visit his father, who was beginning to experience the turbulence of his conflicts with the Michel family as a result of the Las Humedades fraud. In this second trip, he started to become interested in certain topics of Mexican history, particularly those involving the revolutionary figures of Emiliano Zapata and Francisco Villa. Their popular demands fit into the völkisch ideas that he would develop later on. However, the goal of this second trip was much more earthly, although no less romantic. In the company of Disselhof, Per began to search pre-Hispanic tombs and treasures to supply the expansive European market for antiques and exotic objects. It does not appear that he was very successful, although a third trip in 1939, accompanied by his wife, Liv, would also have this pretext, in addition to visiting the properties that his father was trying to save from the Colima pillage. That would be the last time that Per would step on Mexican soil. ${ }^{16}$

The experiences in Mexico were especially important for Per, who devoted many of his reflections on them in his writings. Perhaps the most important trip was the first, of $1927-28$, as it was to that one that he dedicated his book Das Land Noruega: Erlebnisse in Mexico (The country of Noruega: Experiences in Mexico), which was published in German in 1936 by the publishing house Insel Verlag of Leipzig. Surprisingly, the book was moderately successful. Per was then twenty-four years of age, and Das Land Noruega became a reference point of the passionate, adventurous, and nationalist youth, as extolled by the Nazi ideology. ${ }^{17}$ In this account, in which fiction coexists with reality, Per managed to expound on some of the key ideas of his youth. Both the geography and recent history of Mexico served as a pretext to reflect on the superiority of the white man over the indigenous and mestizo world. The idea of a "Norwegian" model of strength, wisdom, passion, and willingness for adventure, acting against an alienated, taciturn, and inferior population, extends throughout the entire text. It is also a kind of journey into the unknown - an excuse to delve

\footnotetext{
15 Terje Emberland and Bernt Rougthvedt, Det Ariske Idol. Forfatteren, eventyreren og nazisten Per Imerslund (Oslo: Aschehoug, ), 118-119.

16 Ibid., 337-340.

17 Ibid., 224-241.
} 
into the consciousness and intuition of the author. The confrontation between fiction and reality was used to insert various images and dimensions of representation and memory, confronted with the certainty of danger and death.

\section{The Mexico of Das Land Noruega}

The book begins with the arrival of young Per Imerslund in Colima, at the Las Humedades plantation, located on the coastal area near the city of Tecomán on the banks of the Almería River. ${ }^{18}$ All of this land is watched over by the huge mass of the Colima Volcano, showing its igneous activity with the continual tuft of white smoke.

The text never stated who owned the plantation. But the administrators were Mr. Arrow, from the United States, who was a reserved, hunting enthusiast and great drinker of whiskey, and the German accountant Papenhofer, an excellent bookkeeper and a highly educated man. It is likely that this character was inspired by the figure of Hans Dietrich Disselhof.

The plantation was adjacent to a cattle ranch and salt bed owned by Eliseo Castañeda, a Mexican mestizo "gentleman." When the main character, Per himself, arrived in Colima, Papenhofer was lodged at the Castañeda hacienda because he had been stricken by a malaria outbreak.

Per arrives at Las Humedades with a one-year contract as foreman, in charge of forty coconut cutters. When he goes to the adjacent hacienda to present himself to Papenhofer, the man tells Per:

This hell is extraordinarily beautiful and that is what is dangerous. Here one dies without knowing it. When you know it, then it's already too late, because you can stay here all your life and curse this hell, which so resembles a paradise. Go away from here before you lose the ability to laugh. You're too young for this paradise. ${ }^{19}$

The idea of the paradise/hell duality appears throughout the book as a central element that constantly adds tension to the plot.

Don Eliseo and Papenhofer spent their days playing chess and drinking lots of tequila. But they also read and discussed Schopenhauer, Calderón, Goethe, Kant, and Nietzsche. All this seems somewhat implausible, but it allowed the author to demonstrate his knowledge and discuss certain philosophical issues,

\footnotetext{
18 All the references to Das Land Noruega: Erlebnisse in Mexico correspond to the first edition published in German by the publishing house Im Insel, in Leipzig, in 1936.

19 Ibid., 34.
} 
such as the superiority of the Western intellect, and the importance of passion, civilization, and nature. Per described his early days as follows:

I had plenty to do in my daily life. Horseback riding and watching over the workers was the least of it. I took that as a sport. While I trained to keep the horse at a steady pace, I admired the incredible abundance of the landscape. It was not a feeling of sheer joy. Rather it was a strange serenity. The life that unfolded around me was overwhelming. ${ }^{20}$

In those first pages, Per emphasized the importance of the landscape as a completely wild and untamed world. The jungle, the river, the ocean, the sunsets, the colors, and the flowers impressed him enormously. Nature appeared so formidable that the author ended his reflections by acknowledging that "this landscape is much more alive and powerful than any other I know," including that of Norway. ${ }^{21}$ An ocean phenomenon that especially drew his attention was "the green wave." It was a huge wave, perhaps a tsunami, which occasionally ravaged the beaches of the region and that for a long time had given rise to many myths and legends. ${ }^{22}$

In terms of the human landscape, Per described Francisco, the butler of Las Humedades, as follows: "He is more than a brown mestizo, more than a wellgrown and articulated animal."23 He had the skin of an Indian, but the face of a Spaniard. He always spoke badly of the Americans, the "gringos." He told stories about having gone north to work, but he always returned to his country and to his plot of land because he missed the tortillas.

The author seems very impressed by the fact that Mexico is in constant revolution, and he expresses admiration for men who fight for their "honor." He also extols the fury of nature, as represented by the floods, waves, and

\footnotetext{
$20 \quad$ Ibid., 43.

21 Ibid., 51.

22 Tidal waves that produced these huge waves, generically called "green waves," were recorded since the end of the nineteenth century. In 1925 there was a green wave that was so big that it virtually wiped out the town of Cuyutlán. But probably the most catastrophic occurred on June 22, 1932. The Excelsior newspaper described it as follows: "The waters of the ocean retreated in a violent manner, forming the appearance of a monumental wall that did not look like a wave but rather a vertical front. This avalanche withdrew three hundred to four hundred meters offshore and soon advanced with unprecedented force in the direction of the village. The Dantesque avalanche advanced destroying and razing everything in its path." Excelsior, June 23, 1932. See José Salazar Cárdenas El maremoto de Cuyutlán (México: Sociedad Colimense de Estudios Históricos, 1989).
}

Imerslund, Das Land Noruega, 55 . 
earthquakes produced by the volcano. But what seems to interest him most is horseback riding in the jungle, swimming in the ocean, and, above all, hunting jaguars.

As the story advances, Per gradually discovers that he has begun to get bored, and he realizes that the Mexican Indians do not accept him. He has the impression that Las Humedades has conquered him:

I could hear the roosters crow and the donkeys bray. This cursed homogeneity. I lay waiting for the next cock crow and the next bray. I counted the hours and could not sleep. I felt that time went by and left me behind. ... With every cock crowing, years of my life were being consumed. ${ }^{24}$

When asked about Norway, Per expressed pride in his country, saying that it was a great nation. He presented an idyllic image that seemed to impress his listeners, who, according to him, formed a noble idea of that country, although for the experienced reader it seemed that the author was full of irony:

In my country there were no robberies, nor murders; the police had nothing to do. Unity and peace reigned in the parliament. Politicians only thought of the good of the country.... Norway has had 130 years of lasting peace...because no one dares to attack us... We have an army whose soldiers do not earn money, each one serves the country for a full year... There is always a rifle at home, and if someone attacks the country, all Norwegians, from the oldest to the youngest, would give their last drop of blood for freedom. ${ }^{25}$

According to the author, Mexicans were more impressed when he told them that Norway had fought against the United States and had won. He said that the "gringos" paid tribute to the king of Norway and that the king would soon come to Mexico on a warship that was much larger than those in the United States to talk with the president. ${ }^{26}$

The fantasies about his country seemed to convince his audience. Each time Per mentioned Norway while he was speaking, he presented the country as a nation he wanted to believe in - not the Norway where he had lived and that had nothing to do with his dreams and utopias. Only once did he write about receiving a telegram from the consul of Norway asking him if he was doing

\footnotetext{
24 Ibid., 114.

25 Ibid., 153.

26 Ibid., 127 .
} 
well. But then he acknowledged that he did not want to know anything about this homeland. ${ }^{27}$

On his trips to Tecomán and to the beach, Per gradually felt a kind of love for the Colima Volcano, which he evoked in the following way:

Perhaps one is lucky enough to have such a great desire, an unattainable longing that eventually causes one to trust in oneself. And I thought about the meaning of longing for the unattainable, because I myself was in love with the Volcano. ${ }^{28}$

From that moment on, the volcano acquired the meaning of a longing, a kind of utopian destination that would push him to go ahead and opt for the adventurous and passionate life, consistent with the designs of nature.

In the second part of Das Land Noruega, Imerslund put aside his impressions of the geography and the environment to give way to a story filled with adventures and reflections. Leaving his boredom behind, Per befriended a mule driver named Rodrigo Guzmán and decided to join the street vendors who sold goods and horses, abandoning Las Humedades. When he said goodbye, he was paid 853 silver pesos and he rode off with his friends toward the mountains. Thus, they became the "night riders."29

They took the route to Tepames and decided to dedicate themselves to mule driving and trade. Per and his friend Rodrigo appeared as the leaders of that gang:

Rodrigo was as tall as me. With his gray-blue eyes, sharp gaze, and fire-red hair, he looked more like a Norwegian farmer than a Mexican. He told the other muleteers that we were relatives, except that I had grown up abroad. $^{30}$

The authority of both men seemed to rest mainly on their image as foreigners white with light eyes, irradiating their superiority over the Mexican Indians and mestizos. In their wanderings they began learning about the Cristero War then sweeping through the region near the volcano and the western Sierra Madre

\footnotetext{
27 Ibid., 98.

28 Ibid., 121

29 "Nacht Reiter die weder Genspenster noch Menschen fürchten" Ibid., 139.

30 Ibid., 144.
} 
Mountains. ${ }^{31}$ At the El Zarco ranch they were told that in Colima several massacres had occurred and that the insurgents had united under the cry "Long live Christ the King!" The war between the Catholic Church and the postrevolutionary government would then become the scene of the adventures of Per and his friends. The author used this to comment on religion, particularly Catholicism, which he did not admire at all. Rather, he felt that Mexican Catholicism was an example of a particularly negative fanaticism that permitted the exploitation and misery of most indigenous and mestizo Mexicans. In that sense, Imerslund expressed an insight that identified him more with the revolutionaries than with the Catholics.

But back to the story and to the insecurity that persisted on the mountain roads, Per and Rodrigo decided to go to Colima to buy products for the mule trade and to remain for some time away from the region where the Cristeros were. When they arrived in Colima, they found the city full of soldiers. The fight did not seem to be only between the church and the revolutionary government, but between agraristas ${ }^{32}$ and Cristeros. The narrative then stops for comments on certain aspects of the land distribution by the government, which Per appeared to support. He argued that land gave meaning to the people and the nation, just as the southern forces of Emiliano Zapata and the northern militias led by Pancho Villa proclaimed. At one point Francisco, "an agrarian," even tried to convince Per and Rodrigo to join the government forces. But they refused and decided to wait on the outskirts of Colima for the arrival of the tools and goods they had ordered from Guadalajara to supply themselves and continue their travels though the mountains.

In another digression, the author recounted some of the everyday, popular, and traditional activities of Colima in a tone similar to that of a folk chronicler. Cockfighting, encounters between men and women in the plaza, having a drink in the plaza, and sitting back and watching the entry of the troops and observing las galletas ${ }^{33}$ were interspersed in Imerslund's descriptions. A special mention was devoted to eating tacos, which was regarded as the national dish ("Nationalgericht"), as well as watching girls carrying water. Per seemed to

31 This war broke out between the Church and the postrevolutionary Mexican state between 1926 and 1929. It was especially fierce in the western part of the country. In Colima it gained some importance due to the ruggedness of its geography and proximity to the coast. See. J. Jesús Negrete Naranjo, Guerrilla Cristera. Sur de Jalisco, Volcán de Colima y Michoacán (México: Ed. Glamourama, 2009).

32 The agraristas were the peasants to whom the government had granted a parcel of land, or ejido, as payment for their services during the revolution or in response to their demand for land to be able to survive.

Las galletas were the women who accompanied the troops, the soldaderas. 
be fascinated with this scene, and he evoked it with romanticism in the following manner:

How beautiful are the women who carry water jugs on their heads. They know they are beautiful. When we ride alongside them, they move their hips and raise their chest. They smile when we prod the horses with spurs, and they lower their shawls to bare their shoulders. They bring water from the same fountains where we swam like excited children. Water that gives life when the roots of the palm trees drink it. ${ }^{34}$

The two friends ended up settling in an abandoned church outside Colima. After burning the wood from the pews, they discovered that the neighbors were afraid of them. They told the two men that they were Protestants and allies of the devil. While they were killing time, Per and Rodrigo found a small burial site in the church courtyard. They thought that they were pre-Hispanic pieces because there were "painted monkeys" on them. This allowed the author to mention the legends of treasures and superstitions that he had heard at Las Humedades. Per had been very impressed by the story of a landowner who had made a pact with the devil so that he could find out where the pre-Hispanic treasures were and thus become immensely rich. ${ }^{35}$

Following a certain fascination with Mexican nationalist mythology, Per interpreted the Cristero War as the battle between the serpent and the eagle that made up the Mexican national shield. He also commented on the importance of the Virgin of Guadalupe as another symbol of national unity. He even went so far as to say in a somewhat simplistic way, much in the way of a Volk story, that the "eagle and the Virgin of Guadalupe are friends, but the bishops want them to always be fighting." 36

Finally, the two friends received their products from Guadalajara and resumed their mule trading trips. They bought twenty-two oxen with their earnings. But during a holdup, the Cristeros stole everything. Per and his partner were imprisoned and kept isolated, but they managed to get the guards drunk and escaped, heading toward the El Platanar hacienda.

In the midst of so much danger, of so much "Long live Mexico!" and "Long live Christ the King!" the author wondered for whom or why would he shout "Long live!" He realized that he had nothing to give his life for because he had lost his faith, his land, his conscience, and the only thing he seemed to have left

$34 \quad$ Imerslund, Das Land Noruega 201.

35 Curiously, Per Imerslund himself, far from the fiction, will try to follow these fables and legends so he can take advantage of them on his future trips to Mexico. 
was his freedom. But this, without the above, had no meaning. One of the daughters of a landowner friend asked him:

"Norwegian, do you want to return to your country?... Norwegian, isn't it beautiful here?"

"Yes, it is very beautiful," I answered and looked again at the view of the landscape.

In the distance, there was the ocean, then a thin strip of land, there was Las Humedades. To the south, the endless mountain ranges stood. To the west, the land, hills with pine and fir trees. And to the north, the Sultan, the Colima Volcano. ...

"Why do you want to return to Norway?"

"It's very easy: I want to go back to feel a bit more relaxed, at least for a few hours. ..."

In Norway, they've forgotten who they are.... The land and those who died for it have also been forgotten. ... They have forgotten everything except their own weakness. ... That is why I want to return. ... To try to find those who also return to Norway and also lied for her. ${ }^{37}$

Per realized that he had lied to himself by claiming that he did not have a reason to go back. Now he had one: He wanted to restore his faith in his country and its destiny. At that moment, he decided to begin his return.

On the way back to Colima, the muleteers followed the tracks of a jaguar and hunted it down. This made Per reflect on the wild world and his fascination for blood and death. The jaguar was a hunter, and therefore it had to contend with other hunters, such as human beings, but not with the Indians whose humanity was constantly questioned, but with white people, who were bigger, and "those with blue eyes" were the best and the most powerful. ${ }^{38}$

Finally, after killing the jaguar, they ran into Francisco "the agrarian," who had left the fields to pursue the Cristeros. And even though they were unable to recover the oxen that had been stolen, the two muleteers were happy because the severely beaten Cristeros had retreated to the slopes of the volcano and barricaded themselves there.

After arriving in Colima, Per received word at the post office that there was a Norwegian ship in Veracruz and that he could soon return to his homeland. He immediately took the train to Guadalajara, and from there he headed to Veracruz to reach the ship that would take him back to Norway. On the way, the

$\begin{array}{ll}37 & \text { Ibid., 239. } \\ 38 & \text { Ibid., 246. }\end{array}$ 
last image that remained of the time he spent in Colima was that of the majestic volcano he called "Der Sultan."39

So the adventures Per narrated in these somewhat fictionalized autobiographical passages present a country that, more than a reality, served as a pretext for claiming his status as a passionate, bold, and determined youth. The conviction that Norway, his native land, would offer itself to him as his destiny appeared as a contrast to the exotic, the inferior, and the unusual. His book was like that, not only an adventure story in a world where nature seemed to govern by itself and in which the unknown and distant corroborated much of its strangeness, but it was also a story of a journey to the interior of a young man who found in the popular, nationalist, and Euro-centric assertions an answer to satisfy his own destiny. The emptiness that left Nordic youth shattered during the period between wars could be filled with many of the expectations that appeared in this text, which no wonder was titled Das Land Noruega: Erlebnisse in Mexiko.

After the book was published with relative success, Per continued with his nationalist assertions that claimed the Aryan and Nordic ideal. His life, like that of many of his comrades in the struggle, was cut short in 1943 in the midst of a war that was both irrational and cruel.

\section{Halfdan Jebe in Yucatán: Antecedents and the Bohemian Life}

The violinist and composer Halfdan Frederik Jebe Klingeberg was born on November 3, 1868, in Trondhjem (modern-day Trondheim), Norway, and died in Mexico City on December $17,1937 .^{40}$

His father, Håkon Gabriel Jebe, was born on February 1, 1831, and his mother Hedvig Jorgine Klingeberg on February 23, 1846. While the death of his father remains a bit of a mystery, it is known that his mother died on December 6, 1925. They married on December 5,1866 . The Jebes were a middle class family with some bourgeois ancestry. Also standing out among the three children was Martha Caroline ("Tupsy"), who would become an artist and the lover of a notable friend of Halfdan: the famous painter Edvard Munch. ${ }^{41}$

39 p. 254.

40 Some biographical facts about Halfdan Jebe can be found in John D. Bergsagel, "Halfdan Jebe," in The New Grove Dictionary of Music and Musicians (London: Palgrave Macmillan, 2001). One can also consult John D. Bergsagel, 'Scandinavia: Unity in Diversity' in Jim Samson (ed.), The Late Romantic Era: From Mid-1gth Century to World War I (London: Palgrave Macmillan, 1991).

41 Sue Prideaux, Edvard Munch. Behind The Scream (New Haven, Conn.: Yale University Press, 2007), 182-183. 
Halfdan studied music in Germany, France, and England. He was a very close friend of Fredrick Delius, who like Jebe had studied in Leipzig. The two would be inevitably influenced by the romantic and nationalist work of Norwegian composer Edvard Grieg. In Leipzig, Jebe, along with Gustaf Dalman, published his first works linked to the era's romanticism, Jüdische Melodien aus Galizien und Russland, taking folk tunes providing them with piano accompaniments. ${ }^{42}$

Between 1894 and 1897, he belonged to the Cologne Orchestra in Paris. Around 1897 he traveled with Delius to Florida, where Delius had an orange plantation. Aboard the ship to New York, one of Delius's lovers, Princesse de Cystria who was Marie Leonie Mortier, daughter of the Duchesse de Trévise, a great patron of the musical life of Paris and whose husband had a large plantation on the island of Guadeloupe, was reunited with Delius. The three gave recitals, announcing themselves as Mr. Delius, Madame Donodossola (Marie Leonie) and Mr. Lemanoff (Jebe) - "one of the more eccentric of European artistic excursions into the New World."43

Jebe and Delius lived together for three months in Florida, strengthening their friendship. In 1899 Delius wrote about Jebe, "He is the only one that is worth something, and the only man I really love." ${ }^{4}$ In that year Jebe led an orchestra in London in the first concert of Delius' music in England and in August returned to Christiania by way of Copenhagen. In 1900 he married Sofie Bernhoft, with whom he presented concerts in which she declaimed and personified fragments of poetry and plays. In early 1901 he traveled back to Berlin, where he joined up with Delius again and met Ferruccio Busoni. ${ }^{45}$

In 1902 Jebe undertook a long journey to the Orient. In Ceylon, (Sri Lanka), he wrote a long letter to Delius suggesting that he (Jebe) used a revolver more often than pen and paper. In a relaxed manner, he added, "I only wish I could use it freely and that I could send you a couple of tasty human hams." ${ }^{\text {" } 6 ~} \mathrm{He}$ also stated that he had traveled much farther than China or Japan. "I have gone out into the world;" he stated "...I have carried an idea to its logical conclusion, I have brought a life to an end, I have died, finished with it - this is the transmigration of the soul."

\footnotetext{
42 This work is dated Leipzig, 1893.

43 Lionel Carley, Delius, A Life in Letters, 1862-1908 (London: Scolar Press/ The Delius Trust, 1983), 112.

44 Ibid., 144.

45 Ibid., 163.

46 Ibid., 228.
} 
He said he arrived in Ceylon from Calcutta, and that he had given concerts in Colombo and Kandy, a place where, according to Jebe, the newspapers stated that he was the first violinist to set foot in those lands. He said he had lived among the natives, and for that reason he was very healthy, because while going through Canton and Shanghai he had focused on the gardens and the opium houses. In this letter he emphatically summarized his position about life: He preferred the libidinous and decadent world over that of discipline and work. With a somewhat obscene phrase talking about Japan he concluded, “Give me a refined old whore, I don't mean fucked out old cows, but faded roses with delicate perfumes." 47

In 1904 Jebe was back in Norway and trying to settle down in Kristiania. Between 1904 and 1905 he worked again with Delius in the concerts of the Delius Orchestra in England and Denmark. After 1906 and until 1916 Jebe and his wife Sophie can be traced in various places in the United States. The beginning of World War I kept them in America. Between 1915 and 1916 Jebe lived in the city of Atlanta, giving concerts managed by Karl von Lawrenz and accompanied by the contralto Emma Van de Zande. ${ }^{48}$ But World War I created enough ill will against anything that sounded Germanic to cause von Lawrenz' concert activity to be discontinued, and the Jebes had to leave Atlanta to possibly move to New York.

After March 1916 he disappeared from the map, although it is likely he traveled through the Gulf of Mexico and perhaps even to some South American setting, because in 1920 he reappeares alone in New York, coming from Santiago de Cuba. ${ }^{49}$ Mysteriously, Halfdan's wife Sophie had returned to Norway during this time, and by the end of 1922 he again journeyed south on his own.

Apparently Halfdan arrived alone in Mexico on December 1922 or January 1923. By the end of that month a woman who signed as Jetti Jebe, probably a new companion Jebe had met shortly after he separated from his wife, wrote to the consul of Norway in Mexico asking if anything was known about Halfdan, because he had disappeared as of October 1, 1922, and the only news she had was from the Hotel Moctezuma and Bellavista in Cuernavaca with an address of 17 Matamoros Street. In March the consul informed Jetti that he had no news of her alleged husband. ${ }^{50}$ By then Halfdan had already decided to stay in Mérida in the Yucatán Peninsula. Just a few months earlier he had turned fiftyfour years old.

\footnotetext{
47 Ibid., 229.

48 Don Gillespie, "Halfdan Jebe in Atlanta" in The Delius Society Journal, No. 149, (Spring 2011), 34-40.

49 Ellis Island/Port of New York Records "Haefdan Jebe" Oct, 14, 1920.

5o Amnrno Koloni i Mexico og Centralamerika Exp. 2065 L.0005.
} 


\section{The Yucatán that Halfdan Jebe Experienced: Music, Mythology, and Education}

During the first years of the 1920s, that is, during the first post-revolutionary years, Yucatán went through unprecedented political and social turmoil. The Socialist Party of the Southeast governed the state, led by Felipe Carrillo Puerto, who according to Halfdan Jebe was the "Lenin of America." ${ }^{51}$ While radicalism took over the discourse, important reforms had been undertaken, including land distribution, the organizing of farmers, and the establishment of an anticlerical, rationalist school. A regional awareness reclaimed local cultural values, with art, archaeology, and especially Yucatecan music acquiring special importance. By 1923 the government of Carrillo Puerto promoted the development of local radio, and popular Yucatecan music was intensely disseminated both regionally and across the whole country. ${ }^{52}$

The rebellion by Adolfo de la Huerta in 1923 shook the precarious postrevolutionary political unity on a national scale, and Governor Carrillo Puerto was one of its victims. At year's end he was overthrown, and on January 3, 1924, he was executed..$^{53}$ The De la Huerta rebellion failed, and the regime of President Plutarco Elías Calles considered Carrillo Puerto as one of its martyrs. The reforms in the state of Yucatán continued after the death of Carrillo Puerto, as did the propagation of art, archaeology, and Yucatecan music.

The region became a powerful magnet that attracted scholars, politicians and artists from many parts of the world. Popular Yucatecan music became fashionable in much of the country, with the likes of Guty Cárdenas, Ricardo Palmerín, and Pepe Domínguez. In the late 1920s the archaeological sites of Uxmal and Chichén Itzá were rebuilt and became prime tourist attractions. ${ }^{54}$ At the end of 1930, Soviet filmmaker Sergei Eisenstein arrived in Mexico; he filmed scenes within the Yucatecan peninsula that would circle the globe, particularly those that established a direct relationship between the contemporary and the pre-Columbian indigenous Mayas. ${ }^{55}$

$51 \quad$ "En norsk komponist som har vært hjemefra i 25 år" Nationen, January 18, 1932. The title of this article: "A Norwegian composer who has been away from home for 25 years" makes clear that Jebe left Norway in 1906 and hadn't been back since.

52 Miguel Civeira Taboada, Sensibilidad yucateca en la canción romántica 2 vols. (Toluca: Gobierno del Estado de México, 1978).

53 Francisco José Paoli and Enrique Montalvo, El socialismo olvidado de Yucatán (México: Siglo XXI Editores, 1977).

54 Gerónimo Baqueiro Foster, La canción popular en Yucatán (1850-1950) (México: Editorial del Magisterio, 1970).

55 Aurelio de los Reyes, Medio siglo de cine mexicano (1896-1947) (México: Editorial Trillas, 1987), 99-114. 
During the 1930s Yucatán would return to revolutionary radicalism. General Cárdenas would foster the creation of the communal agave lands, known as the Gran Ejido Henequenero, distributing the largest amount of land in the history of the peninsula. The vitality of the Yucatecan culture would continue to rise until the late 1930 s and early 1940 . $^{56}$

While the exact date cannot be ascertained, Halfdan Jebe must have arrived in Yucatán between late 1922 and early $1923 .{ }^{57} \mathrm{He}$ established himself in Mérida and began to give music and violin lessons at the local conservatory. He also gave private lessons, "which are the ones that pay the best." 58 It seems that he was very poor when he arrived in Mérida, because in an interview in 1932 he said that when he reached Mexico, he had no money to pay rent for a house, and therefore he had to live in an abandoned church that was loaned to him by some neighbors. Initially he settled in Yucatán, "with an archaeological purpose, to see the wonderful old ruins that are there," but he ended up teaching at the conservatory.59

Evidently he had some degree of friendship with Felipe Carrillo Puerto, which made him a political enemy of the De la Huerta followers in 1923. Ten years later, during a visit to Norway, he told a local journalist that he had been jailed and tortured.

What saved me was that I was a foreigner. But I was imprisoned twice. For weeks I waited to be taken to the solitary cell - a sure sign that I would be executed the next day. The guards tried to allay me with morphine and cocaine - but luckily I did not need them. It was no fun at all to live in Mérida at the time. ... The bodies of those who had been hanged swayed in all the trees of the city park; they tied their heads to a branch and then made a horse pull on their legs. ${ }^{60}$

Jebe was the teacher of several important Yucatecan musicians, such as Vicente Uvalle Castillo, Amilcar Cetina Gutiérrez, Gustavo Río Escalante, and Daniel Ayala. The latter stated in his unpublished memoirs that "drawn to the Maya

$5^{6}$ A clear example of this vitality is the publication of the eight volumes of the Enciclopedia Yucatanense, published in 1945, and which have since become a key reference for the history and culture of the Yucatán Peninsula.

The date of his entry into Mexico in his immigration record is January 28, 1923, although based on the previously mentioned letter from his alleged wife, Jetti, it is probable that Jebe arrived in Mexico in late 1922. AGN Migration Service, Registry of Foreigners. No. 98647 and Amn Rno Koloni i Mexico og Centralamerika Exp. 2065 L.0005.

$5^{8}$ "En norsk komponist som har vært hjemefra i 25 år” Nationen, August 18, 1932.

59 Ibid.

6o Ibid. 
ruins by virtue of also being a specialist in archaeology," the teacher Halfdan Jebe "agreed to teach violin at the conservatory, and it was then that a large number of future violinists enrolled in his class." Daniel considered himself the teacher's "favorite," and Jebe passed on to him "many secrets of the instrument" and turned him into a capable soloist. ${ }^{61}$

Between 1925 and 1935 Halfdan Jebe served as first violinist, occasionally as viola player, and sometimes as conductor of the Mérida Symphonic Orchestra. From his very first performances he was considered "a tireless promoter of Yucatecan music." 62 Little by little his talents as a composer and music critic were also discovered. During those years Jebe also wrote several articles and commentaries in the Diario de Yucatán about the Yucatecan music scene. This allowed him to witness the rise of national and regional music, both Mexican and Yucatecan. While his music was closer to contemporary trends, his romanticism led him to focus on the music that was being played in local academic compositions, comparing them with some European authors.

For example, in 1924 he reviewed one of the first works with a Maya topic that was presented in Mérida. This was the opera Kinchí by Gustavo Río Escalante, which premiered on September 27, 1924, at the Peón Contreras Theatre. ${ }^{63}$ While critics generally felt very dissatisfied with this work because of its technical and historical shortcomings, Jebe defended the piece, pointing out that the music was worth much more than the script. He supported the idea that Río Escalante was seeking a philosophical and dramatic musical language in which instruments acted as interpreters to outdo human power of speech "in the expression of terror and of passions," much in the same way as what leading Mexican composer Julián Carrillo was experimenting with at the time. He also stated that Río Escalante's work had characteristic regional tones, although he still denied the existence of Maya features in the music, in great part because of the enormous ignorance that prevailed then about the art of music cultivated by pre-Hispanic peoples. Nevertheless, Jebe's enthusiasm for the evocation of the Maya world led him to write the following paragraph:

In the opera Kinchí, Gustavo Río has moved away from Donizetti and Verdi, looking for models among more modern authors, and inspiration

61 Daniel Ayala, Memorias inéditas archived in the Regional Center of Music Research, Documentation and Diffusion "Gerónimo Baqueiro Foster" (CRIDDMGBF) in Mérida, Yucatán, 90 and 106.

62 Jesús C. Romero, "Historia de la música" in Enciclopedia Yucatanense Vol. IV (México: Gobierno del Estado de Yucatán, 1944), 740.

63 Gustavo Río Escalante, Mis memorias (Yucatán: ConAculta, 2012), 168. 
in artistic moments of a forgotten past, worthy of resurrection and remembrance. I want it to be known in my old Norway, where a work of art, if it is sincere, is always received with affection. ${ }^{64}$

Four years later Río Escalante composed another opera entitled Xtabay, which premiered on July 31, 1928, again at the Peón Contreras Theatre in Mérida. Jebe commented on the musical style that followed the guidelines of Achille-Claude Debussy, and this time he acknowledged the inspiration of the "pre-Hispanic airs." On this occasion he became very excited by Río's inspiration to turn to the Maya myths, particularly to that of Xtabay, that beautiful woman who hides in the jungle, under a large ceiba tree, and calls the men to lead them astray. ${ }^{65}$ Jebe himself also turned to Maya themes, composing some important pieces with such themes for his repertoire. He premiered those compositions in Mexico and Norway between 1929 and 1932.

During those first years in Mérida, Halfdan Jebe had a romantic relationship with Sara Molina Font, a beautiful young writer. Heiress of a high-status Yucatecan family - of the kind of families known as the "divine caste" - Sara was also one of the first women in Yucatán to seek a divorce from her first husband, abiding by the feminist laws promoted by Carrillo Puerto's government, and she became a liberated woman, promoter of the peninsula's art and literature. After her divorce, which took place almost at the same time of Jebe's arrival in Yucatán she went to live with her parents. The head of this family was Juan F. Molina Solís, a very prestigious jurist and historiographer, brother of Olegario Molina Solís, who was governor of Yucatán and Development Secretary in the government of Porfirio Diaz. ${ }^{66}$

Juan F. Molina took Sara in after her marriage failed, and he demanded that she follow the codes of a rigid Catholic morality. However, Sara continued her vocation as a writer and as a liberated woman. In 1926 she published a book entitled Siluetas (Silhouettes), which brought her some prestige in the learned circles of Mérida. In one of the book's stories, she presented a brief sketch of an absent-minded and passionate musician, probably inspired by Jebe, and she indicated a deep admiration for his work. She described him as follows:

He has the name of a star and works at the altar of Euterpe. He writes music with amazing ease. Does he bear a resemblance to the bust of

\footnotetext{
64 Revista de Yucatán, October 14, 1924.

65 Diario de Yucatán, August 4, 1928.

66 José Maria Valdés Acosta, A través de las centurias vol. II (Mérida: Talleres Pluma y Lápiz, 1926), 11-12 and 22.
} 
Chopin, Berlioz, Liszt?... I am not certain to whom, but he has an unquestionable likeness to one of them. A balding forehead, an unfocused gaze, almost distracted, an air of those who know how to delve into the world of imagination, and one that most people do not understand because it is essential to have an intense interior life.

The dialogue with the character led her to ask him if he had ever forgotten an appointment and had not gone to conduct an orchestra. To which the maestro replied, "I get distracted sometimes, but not so much." What happened was that he let himself get carried away by inspiration, and concluded:

Love! Love! Taken in its sensitive essence, spiritualized - that is what music is. Its intense sweetness is diluted in kisses that go to the heart of Humanity, singing. ... Why should the creators of these wonders not live dazed, outside of time and space, if they touch the divine?67

Sara Molina's prose indicated that she had a particular fascination with the composer, but she did not fully admit to the love bond. ${ }^{68}$ On the other hand, Daniel Ayala asserted that "the great love affair" that Jebe and Sara had was the main reason that the Norwegian remained in Yucatán. He even said in his memoirs that it was Jebe who encouraged him to act on his love for the young violinist Amelia Medina Herrera. His recollection evoked Jebe advising him that "a great love is good, because it helps to stimulate the artist's inspiration; he said this about his young students, but perhaps he really ascribed it to himself in regard to his great romance with Sara Molina." 69

The relationship between Halfdan and Sara had its ups and downs. As will be seen later in this text, the romance also had artistic consequences given that the two collaborated on several occasions; she as a writer and patron, and he as a musician and composer. In a 1930 document, Jebe mentioned that he was married to Sara Molina, ${ }^{70}$ although other versions deny the existence of such a marriage. ${ }^{71}$ However that may be, though Sara's parents never approved of

67 Sara Molina, Siluetas ( Mérida: n. e., 1926), 87-88.

68 One of her granddaughters assured me in an interview that she was not certain that there had been a romantic relationship between Jebe and Sara, although a friend of hers had assured her that there had been one. Interview with Mrs. Isolina Molina Duarte de Sánchez, Mérida, February 13, 2014.

69 Daniel Ayala, Memorias inéditas archived in CRIDDMG BF in Mérida, Yucatán. p. 100-101.

70 Amnrno Koloni I Mexico og Centralamerika Exp L.ooo6 December 18, 1930.

71 Interview with Mrs. Isolina Molina Duarte de Sánchez, Mérida, February 13, 2014. 
such a relationship, she not only provided him with a place to live, wether on the Los Capules farm or on 502 5oth Street in Mérida, but she also occasionally brought him the Molina home's leftovers so that the "poor Norwegian professor" would have something to eat. ${ }^{72}$

The romance, in effect, does not seem to have had much consistency given that Jebe's life in Yucatán was characterized more by disorder and dipsomania. Daniel Ayala said in his memoirs that

he was always disheveled, dirty, very drunk most of the time, and many times he forgot his engagements as orchestra conductor or violinist.... He lived alone in a small cottage - a country-house - provided by Sarita, where he composed his works with a surprising mastery, working almost the way real geniuses do. The natural disorder of the "Study," with sheets of music strewn on the floor, a bad odor from the jumble of wrapping paper bearing decomposed food - tins, mostly - and his overall appearance in his daily life gave him the appearance of a true "bohemian." Many times in a rehearsal or performance, upon opening his instrument case a bad smell assaulted the noses of his companions because along with the violin or viola, in the case there were also some bits of rotten raw meat, stored and forgotten as his food. ${ }^{73}$

Nevertheless, even with all this anarchy and confusion, Halfdan Jebe managed to produce in Yucatán a remarkable body of work that still awaits his vindication as an artist and creator. Toward the end of the 1920s, "captivated by the ancient Maya civilization or what he thought that culture was, he began to compose Mayan music," until years later when it was acknowledged that "there was no serious musical expression in Yucatán, in which... Norwegian Professor Halfdan Jebe was not involved." 74

\section{The Yucatecan Work of Halfdan Jebe}

The Maya ruins and the legends, contemporary history, and landscapes of Yucatan became the favorite themes of Jebe's compositions. Constant references to archaeological sites, sinkholes and caves, characters from myths or from Yucatán's recent history, regional carnival traditions, and the peninsula's

72 Interview with Mrs. Isolina Molina Duarte de Sánchez, Mérida, February 13, 2014.

73 Daniel Ayala, Memorias inéditas archived in CRIDDMGBF in Mérida, Yucatán. p. 101.

74 Enciclopedia Yucatanense Vol. Iv (México: Gobierno del Estado de Yucatán, 1944), 741. 
fauna and flora were woven into symphonic works, operas, and ballets that Jebe composed from the late 1920 and during the 1930s.

In the early 1930s, Jebe, a composer, orchestra conductor, and violinist who was relatively well known in Yucatán, made a trip back to the Old World. He arrived unexpectedly at the home of his old friend Frederick Delius in Grezsur-Loing in France "in a terrible state like the most abject dirty beggar..." and was briefly put in hospital. ${ }^{75}$

Once he recovered he went to Norway, where, besides trying to renew some old relationships, he presented several of his Yucatán compositions in a chamber music concert at the music conservatory and a concert devoted exclusively to his music given in the auditorium of Oslo University by the Philharmonic Society Orchestra, conducted by Olaf Kielland. The program from that concert held on January 21, 1932, included eloquent notes about the works played, which were the following:

1. Entrance to Uxmal (the composition is inspired by the architecture of the Maya ruins)

2. The symphony The Path of Destiny toward the Ideal (dedicated to Felipe Carrillo Puerto - "not the fallen politician, but the man, the idealist")

3. Romance entitled The Sacrifice of the Virgins ("During religious festivals, the country's most beautiful virgins were sacrificed. The romance accompanies the virgins on their walk from the temple to the sacred sinkhole where Yum-Chac, the god of water, awaits his new bride")

4. Music for the ballet The Caves of Lol-Tun ("appearing in this work in addition to the Lol-tun that is, 'Stone-flowers', are the mythical figures of Xtabay and the dwarf Homschuk" $)^{76}$

According to some Norwegian newspaper reviews, Halfdan Jebe's work was fairly well received by local critics, but what was most interesting upon his return to Norway was what the composer had to say about his adventurous life and his opinions of what was going on in Mexico at that time. A few days before the Oslo concert, Jebe was interviewed by the Nationen newspaper, which on January 18 published a long article. A few excerpts follow below:

Yes, quarter of a century! Indeed, it is twenty-five years since conductor and composer Halfdan Jebe left Norway. Now he is back - a bit awestruck, but not discontented - to see if his compatriots also want to give him a

75 Lionel Carley, Delius, A Life in Letters, 1908-1932 Vol. II (London: Scolar Press/The Delius Trust, 1983), 376.

76 Concert program consulted in Nasjonalbiblioteket in Oslo. 
chance, as the Mexicans have done.... His music has been performed on radio broadcasts and by various philharmonic orchestras. He is a man from whom one can patiently wait for an answer.... And now he is sitting here waiting for us to ask a question.

[Interviewer:] "Where have you been all these years?"

[Jebe:] "First in the United States and then in Mexico. For eight years I have been a professor at the State Musical Conservatory in Mérida, the capital of the state of Yucatán, a city the size of Bergen. When I arrived there, it was not to find work, but rather it was with an archaeological purpose, to see the wonderful old ruins there. And I stayed. I was hired at the conservatory, where I taught composition, and also violin and piano. I also had many private students - it is what pays the best."

"What is it like to live in Mexico?"

"It is a beautiful country. I wish it were not so troubled. In the last twenty years it has been devastated by revolutions. In Mérida I met one of the best men I have ever known, the anarchist Felipe Carrillo; they called him the red governor...the Lenin of America. He was an honest man. That's why they put him up against the church wall and executed him along with his brothers and friends. When he died, he did not leave behind a penny, while those who succeeded him have been enriching themselves without stopping in the name of socialism. I have written a symphony in honor of that hero."

"What is it like for an artist to live in Mexico?"

"The artistic level in the country is high, especially in literature. One of every two people writes verses and some are very good. Newspapers are also first class. And now Mexico has a composer that may signal a new era in the musical history of the world: the Indian Julián Carrillo. He is not a relative of the liberation hero. The name Carrillo is as common there as Olsen and Hansen are here. Carrillo continues the path indicated by Delius and Schoenberg: toward micro-chromaticism. Carrillo could represent a musical revolution, and it is only natural that such a revolution comes from Mexico, which is imbued with music. It is truly disturbing that the same country that threatens Mexico politically, also does so musically: The United States is the terrible country of jazz."77

While Jebe's compositions were well received by the Norwegian public, at the end of 1932 he decided to return to Yucatán. Once he settled in Mérida, he dedicated himself again to promoting and encouraging the local musical activity. His enthusiasm reached the point where he insisted that Mérida should become "the Bayreuth of the New World." He stated eloquently, "And I, who am

“En norsk komponist som har vært hjemefra i 25 år” Nationen, January 18, 1932. 
in love and grateful to this land that has evoked within me so many artistic feelings, place a humble stone in the great monument to Yucatán." His passion for everything Yucatecan spilled over as he stated the following: "Yucatán, center of all that is America, as Germany, is the heart of Europe, has the divine mission to erect a temple of art, promise, and welcome to every traveler or tourist who arrives to see its greatness!"78

In 1933 Jebe presented his first opera in Yucatán. It was titled Maya Dignity and its central theme was the conquest of the Yucatán peninsula by Spanish soldiers. The music, arrangements, and part of the lyrics were by Halfdan Jebe, while other portions of the lyrics were by Sara Molina. ${ }^{79}$ The main characters were Zuzul and Zacnicté, prince and princess of the Mayab. They were getting married when "the only cloud that could taint the sky of our people and the dream of happy engagements would be the approach of the white people." And right in the middle of the ceremony the conquerors burst in and destroy the town, abducting the women. Zacnicté is abused by the captain of the conquistadors. In a short while, Zuzul and the Maya peasants surprise them in the middle of an orgy. Zacnicté asks Zuzul to save her, but he refuses and kills her after slaying the captain. The people rebel and kill Zuzul.

The opera included very romantic and dramatic moments. For example, during the wedding ceremony, Zuzul sang these lines to his beloved:

You are the dawn of my existence

The pure and radiant light

And my path is enchanting

If illuminated by your love. ${ }^{80}$

In that same ceremony, a vestal sings the following lines to Zacnicté:

Born on a divine moonlit night

Her eyes kissed by the ardent sun

That is why there is nectar upon her rosy lips

And burning fire in her heart. ${ }^{81}$

The same opera had some scenes aimed at showing the Spaniards in a bad light. For example, when the conquerors burst into the temple where the marriage was taking place, they did so with the following refrain:

\footnotetext{
78 Arte y Turismo brochure fall issue 1933 consulted in CRIDDMG BF in Mérida, Yucatán.

79 The unpublished score is in Nasjonalbiblioteket in Oslo 2004, eske $15^{2}$.

8 o Ibid., 12.

81 Ibid., 15 .
} 
We arrived and conquered, without killing or dying,

All enemies have fled from here

Without fear or worry, let us now drink

Now we give in to the pleasure of living. ${ }^{82}$

The orgy was accompanied by coarse soldiers choruses:

\author{
Women, delicious women \\ Let's enjoy the triumph and the victory \\ That they will give us, \\ For they are the glory \\ The glory of Mayab. ${ }^{83}$
}

At the end of the opera there appeared a strange reference to a so called "forgotten socialism" in the postrevolutionary Yucatán peninsula. After the death of the main characters, a chorus of farmers sang the following verses:

The tyrants died in the sacred Temple,

Dignity avenged, duty consecrated;

Let's open our eyes wider to the sublime truth:

The joy of work is a greater dignity....

Long live the Mayab sun! Let freedom arrive!

Long live the Mayab sun! Long live brotherhood!

Let the new era for humanity arrive! ${ }^{84}$

This would not be the only reference in Jebe's work to fraternity, liberty, and the new era for humanity. As will be seen later, these ideas seem to have been aroused in the composer's mind on his return to Yucatán. Perhaps his own decadent life had brought him closer to those notions linked to anarchism, although it is fair to say that Jebe's work never avoided political issues or libertarian messages. Maybe these ideas were even reinforced by the free spirit of Sara Molina, but especially by the atmosphere and the socialist discourse that would soon reappear in Yucatán with the arrival of the Cárdenas ideology on a national level in 1934.

Indeed, between 1934 and 1940, during the administration of President and General Lázaro Cárdenas del Río, the winds of radical socialism blew across almost the entire country. And while for many it was more about speeches and demagogy than about implementing socialist reforms, Yucatán

\begin{tabular}{ll}
\hline 82 & Ibid., 16. \\
83 & Ibid., 21. \\
84 & Ibid., 24.
\end{tabular}




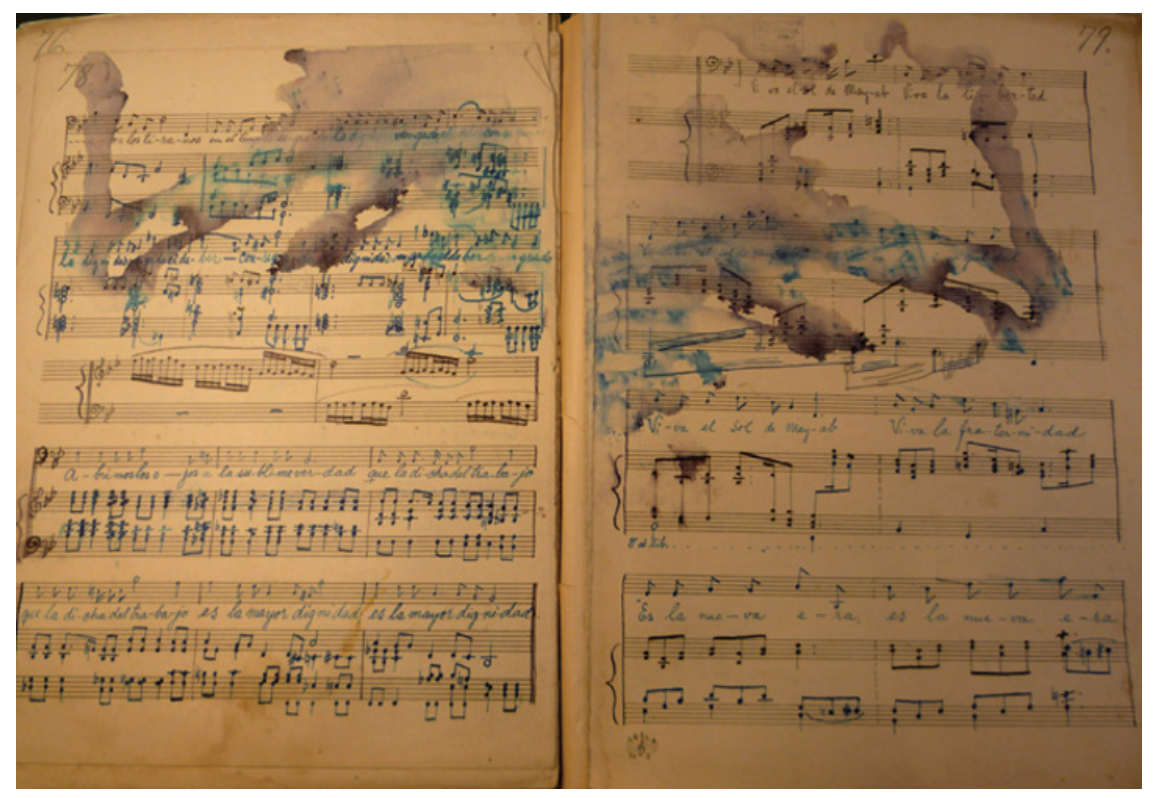

FIGURE 8.1 Fragment of Dignidad Maya by H.Jebe ORIGINAL SCORE AT NASJONALBIBLIOTEKET, OSLO

was particularly sensitive to this shift to the left being carried out by postrevolutionary Mexico.

On December 26, 1934, the symphonic poem Uxmal by Halfdan Jebe was presented again in Mérida, and it was received with great enthusiasm by the local public. The report of this performance stated that the Mérida Symphony Orchestra, conducted by Francisco Sánchez Rejón, first played the overture of Helios by Carl Nielsen, and then, conducted by Luis G. Garavito, a Serenade by Mozart. Next appeared "before the orchestra the likeable Halfdan Jebe, the great Norwegian musician who has made of Yucatán a suitable little corner for his dreams as an artist." After describing his passionate way of directing the opening chords of his symphonic poem Uxmal, the reporter said that the Norwegian conductor seemed to grow while on the podium: "The orchestra is all his. It has yielded to him as would a passionate girlfriend, trembling with multiple feelings, soft and affectionate toward the hand that commands but at the same time caresses with youthful impulsiveness and infinite human warmth..." The literary description of his music was also a bit exaggerated. According to the reporter, "His music, which adds admirable modernisms to certain details of deep romanticism, beautifully constructed, possessed of a teenager's temperament, ardent, passionate, the soul of a true artist." 85

Diario del Sureste December 27, 1934. 
In 1935 musician Samuel Marti traveled from El Paso, Texas, to Yucatán to collect Maya musical folklore. In Mérida, Martí met several notable Yucatecan musicians such as Amilcar Cetina, Luis Garavito, and Halfdan Jebe. At their initiative and sponsored by Clemente López Trujillo, editor of the newspaper El Diario del Sureste, the Yucatán Symphony Orchestra was established in early 1936 and the conductor was Martí. Halfdan Jebe shared the first-chair violin with Luis Garavito. During the orchestra's two seasons from 1936 to 1938, several of Jebe's works were performed, notably his symphonic poems The Caves of Loltún and Chichén Itzá. The opera Maya Dignity was also staged again. ${ }^{86}$

In the score for The Caves of Loltún, which incidentally appeared on the program under the title The Rain Parties, Jebe included a composition titled "Xtabay" in which a soprano, a counter-tenor, a tenor, and a bass sang in the Mayan language. The very languid melody included these lines:

Tuux cu tipil kin, Ti yan ya'mail

Jac u tokil tún

Bey lool cuxi thil ¡Loltún!

And later a choir sang in Spanish the following simple lines:

As soon as the sun's gleam gilds the East

The worker grabs his axe and heads toward the field.

Very happy and satisfied he goes with great devotion,

Because he knows that work is the best religion. ${ }^{87}$

The inclusion of texts in Maya and Spanish provided material for Jebe's lyricism, which by the mid-thirties seemed to include elements of modernism. While he had not entirely abandoned the nostalgic evocation of his homeland, ${ }^{88}$ a definite emphasis on his Yucatecan and Maya themes rooted him to the Mexican regional and national music of that moment.

86 Jesús C. Romero, "Historia de la música" in Enciclopedia Yucatanense Vol. IV (México: Gobierno del Estado de Yucatán, 1944), 735-736.

87 Nasjonalbiblioteket in Oslo, 2001c, eske 150-155.

88 Musicologist John Bergsagel observed that a piece by Jebe entitled "Primavera" [Spring], which appeared amongst his Yucatan papers, was a translation into Spanish of his cantata "Lad Vaaren komme," based on a poem by J.P. Jacobsen. It appears that Jebe himself, in an outburst of nostalgia, decided to translate those lyrics into Spanish to try to spread his work as well as that of Jacobsen among the Spanish-speaking public. The work began, "My heart will have its rare spring - when?" According to Bergsagel, Jebe's translation does not seem to do Jacobsen's Danish original full justice. See John Bergsagel, 
In 1936, Jebe dedicated himself to composing and arranging a new suite titled Mérida Carnival, which, though sometimes performed as a suite of five parts ("The Corsair," "The Queen," "Soul of the Guitar," "The Dirty Old Men," and "The Passions"), actually consists in the full score of at least eight more movements. In total it had thirteen relatively independent parts: 1. "The Corsair" (also titled "The Governor"), 2. "Soul of the Guitar," 3. "The Dirty Old Men," 4. "The Drunkard" ("Silhouettes"), 5. "Hostesses" (or "Pretty Mérida Natives"), 6. "The Queen," 7. "Mestiza," 8. "The Blind Man," 9. "Mexican Matters," 10. "Passions," 11. "Top Rooster," 12. "The Parish Priest," and 13. "The Dance." 89

The compositions tried to represent some of the key moments and people of the Mérida carnival. Again using some elements of the popular world, Jebe musically recreated various aspects of the celebration. For example, the scene in Top Rooster asked participants in the carnival represented in a choir to sing the next chorus at a martial rhythm:

\author{
Ten-te-re-sé \\ Le-van-ta-té \\ Eh-Oh-Eh \\ I am the top rooster \\ Protector of my hens. \\ Friend of the home \\ The sun rises upon my call \\ To give light and color \\ To my deeds of love. \\ Ten-te-re-sé. ${ }^{90}$
}

A sort of political awareness reappeared in Jebe in this suite. It seemed that he wanted to title his scenes as The Proletarian or Global Indignation; however, he crossed out those titles yet maintained the social criticism. In the last scene corresponding to The Dance, the composer suggested that "mixed in with the hubbub of the party in which everyone takes part, is the clamour of the dispossessed for their inheritance, asking for food, if not for happiness." The final chorus states:

I have not seen you, nor have I heard you Heartbeat of new humanity

"J.P. Jacobsen and music" in J.P. Jacobsens Spor i ord, billeder og toner. Tolv afhandlinger (Copenhagen: C.A. Reitzels Forlag, 1985), 305-306.

$89 \quad$ Nasjonalbiblioteket in Oslo, 2002, eske 151.

9o Ibid. 
But I feel you inside my chest

With thumping, thumping, thumping anxiety. ${ }^{91}$

During this period, Jebe's creativity was stimulated by a new collaboration with Sara Molina. The writer had proposed to create a work for children that unfortunately the composer would not live to hear, for it would be premiered after his death. What was originally presumably a children's ballet - perhaps even a little opera - has survived as an orchestral suite, "The Squirrel," composed of twenty-one parts. Each one represented an example of fauna with a certain link to the culture of Yucatán or Mexico. The work began with a parade of animals and continued with little vignettes of birds such as vultures, cardinals, or mockingbirds, proceeding with a cat, a pig, a monkey, a squirrel, and a toad. One piece referred to a Maya children's song titled "The Xtoles" and others concerned endemic birds of Yucatán such as the xcoquita and chinchimbocal. Halfdan Jebe included the composition of a foxtrot which was titled "The Pig's Foxtrot." Another vignette bore the name of "History of Pérez the Mouse," which referred to an animated character very popular in Mexican children's stories. The last part consisted of two pieces: "Beautiful Childhood" and "Death of the Squirrel."

The complete score of this orchestral suite demonstrated a work that was thorough and caring, characteristic of a sensibility akin to a tenderness for and a love of children. This was a different phase of Jebe's work, which revealed a strong influence from Sara Molina. Surely Jebe knew The Carnival of the Animals by Camille Saint-Saëns, and it probably served him as a reference. However, one must recognize that The Squirrel is contemporary with Peter and the Wolf by Sergei Prokofiev. The orchestral suite from a Norwegian and a Yucatecan - amid Mexican musical nationalism - thus took its place between The Carnival of the Animals and Peter and the Wolf as a contribution to "classical" music for young audiences.

In this last year of his life Halfdan Jebe continued to contribute to Mérida's musical society with the formation of The Modern Singing Maestros. By using this title Jebe was presumably making a reference to the medieval German "Meistersinger," as in Wagner's "Die Meistersinger von Nürnberg." A manuscript of that year titled "The Red Hand: Hymn," which was found among his works, was dedicated to this society. It was a sort of march that had particularly militant lyrics that read:

This is the red hand that represents freedom.

The noble exploits us, so against the noble we are ready to fight. 
This is the red hand, fighting hand hard furrow that gives us bread.

No more exploitation!

Neither Nucuch and masters, nor slaves evermore.

Whoever wants to be a tyrant, the red hand will crush him.

Hand that fertilizes, hand that hurts,

Hand that strengthens brotherhood.

Hand that signals new directions,

Calloused, it is always friendly. ${ }^{92}$

It is not very clear if the idea of the "red hand" was a reference to some symbol of anarchism or if it had some connotation linked to Maya mythology. ${ }^{93}$ What is striking is the vehemence with which, at this point, Jebe expressed his liberal ideals or those of his co-writers. In any event, in this piece there seems to be a strengthened vigor and impetus to continue promoting freedom and the struggle.

Apparently The Modern Singing Maestros did not attain the importance that Jebe and some its members hoped for. Perhaps their music appeared too radical for the Yucatecan society of that time, although it is fair to say that it was a reaction to the environment of radicalism that the Cárdenas regime was imposing - as has already being said - on a great part of the political and agrarian discourse of the day. The night that they made their first presentation, only a small group of people went to the auditorium. One participant recalled: "What sadness there was in the soft blue eyes of the maestro on the evening of our presentation to an audience of two dozen people! He declared himself defeated." ${ }^{94}$

In early 1937 he went to Mexico City, where he worked doing some orchestrations for XEW. On several occasions Jebe himself had written some panegyrics about radio, and it was known that he admired this medium, which to him had a huge future responsibility. He wrote pronouncements such as this:

Radio is the latest musical instrument of artistic, practical and commercial communication. ... We call on the artists, those who are true artists,

$92 \quad$ Nasjonalbiblioteket in Oslo, 2018, eske 154.

93 Cinnabar red is the colour of gloriuos death in Maya mythology. According to John D. Bergsagel, La Mano Roja (The Red Hand) seems to have been a Mayan play, subtitled "Emotivismo legendario en tres estampas, original del Prof. Victor M. Martinez H. con música de Halfdan Jebe y Rubén D. Herrera." Jebe seems to have made a suite from the music, perhaps a ballet but he allegedly is not responsible for the text.

Diario del Sureste December 22, 1937. 
to attain dominance over this heavenly medium, product of the human mind and a tool that is representative of our era. ... As the piano is the soul of the home, the Radio should be the soul of the Universe. ${ }^{95}$

But upon arriving at the capital, he did not adjust to the life of the city. He said, "Here I cannot daydream as in Mérida!" But "by then alcohol was for him an imperative demand and his health declined visibly because of it."96 Pneumonia sent him to the General Hospital, where he died on December 17, 1937. When friends tried to see him, his body had already been sent to the Dolores Cemetery.

On December 22, 1937, Jacques de Bourges - probably a pseudonym for Fernando Burgos Samada, a Mérida conservatory teacher and Jebe's friend and colleague - wrote an article in the Diario del Sureste newspaper titled "Halfdan Jebe has died." In the article he recalled the musician and teacher. After a general description of his shortcomings - stating that he was "the perfect model of last century's bohemian" and someone "who fortified the flow of his musical culture and of all genres, for Jebe was a true scholar" - he acknowledged that a devil had possessed his soul from his early days:

Jebe was born afflicted with bohemia, attacked by that incurable ailment, which is fatal in some of its manifestations. The Norwegian musician's sickness was like one of those neoplasms that destroy the miserable body without anyone being able to do anything about it...

Indeed, Jebe had arrived in Yucatán with that affliction:

That man to whom clothing mattered not a whit, who lived only within sharps and flats, despite his neurosis that separated him very frequently from the realities of life, he worked with courage. He played in orchestras, gave some classes, and he composed, attracted particularly by the enchantment of the Mayab he loved. ${ }^{97}$

De Bourges then summarized the pessimism at the end of Jebe's life when Jebe felt defeated by the failure of The Modern Singing Maestros. He said that Jebe died in a hospital bed, "Sad. Alone. Or perhaps with Mimí at his side. A Mimí

95 Arte y Turismo brochure fall issue 1933 consulted in CRIDDMGBF in Mérida, Yucatán.

96 Jesús C. Romero, "Historia de la música" in Enciclopedia Yucatanense Vol. IV (México: Gobierno del Estado de Yucatán, 1944), 741.

Diario del Sureste, December 22, 1937. 
who undertook the heroic task of sweetening the musician's loneliness." ${ }^{98}$ And who was that Mimí? The truth is that we do not know: Bourges may have been referring poetically to the tragic Mimí of Puccini's La Bohème, but more probably to Jebe's Yucatecan lover, Sara Molina Font. What is certain is that Sara Molina took care of organizing the performance of their shared work, The Squirrel, on July 16, 1938, in the Palace of Fine Arts in Mexico City. ${ }^{99}$ The suite was presented under the title The Squirrel: Maya Fable, and critics treated it fairly well. The Excelsior newspaper said it had been a "lucid festival" that was "rewarded by the public's encouraging reception, thrilled by the work and its minuscule performers." Students from the Benito Juárez School and the Fine Arts Dance School, directed by Lily Cornils, staged the simple story line about "the party of the squirrel, who when it abandons its refuge, falls prey to the hunter." Antonio Mediz Bolio, a celebrated Yucatecan writer living in Mexico City, praised

the conception of the matter, full of originality and simple and pleasing beauty, an artistic vehicle of a sweet philosophy and delicate emotions. ... This beautiful work also has...the singular characteristic of being made with the ever mysterious spirit of the ancient land of the Mayas. ${ }^{100}$

The children's warm applause for the author of the fable, the director, and the performers capped this posthumous tribute from Yucatecans and Mexicans to the late Norwegian composer Halfdan Jebe.

\section{Ola Apenes in the Valley of Mexico: Between Engineering and Archaeology ${ }^{101}$}

Ola Apenes Morch was born on August 23, 1898, in Fredrikstad and died in Canada on April 6, 1943. He was the son of Georg Apenes (1869-1902) and

$98 \quad$ Ibid.

99 Excelsior, July 14, 1938.

$100 \quad$ Excelsior, July 21, 1938.

101 Lars Lervik Langås did a master's thesis at the University of Oslo in 2012 titled Ola Apenes: En norsk migrants forhold til Mexico, 1929-1943. To date, it remains unpublished. For those interested in the letters that Apenes wrote from Mexico, as well as his intimate impressions, views, and opinions about the country, this work is essential. Also in 2012 the production company Flimmer Film made a documentary series for Norwegian television called Glemte helter (Unsung heroes). The segment made by Paulo Chavarría Serrano, a young Costa Rican filmmaker based in Bergen, was dedicated to Ola Apenes. This documentary, which was very well researched and excellently directed, gives a fairly complete 
Cathinka "Kitty" Morch (1872-1958). They had two sons, Ola and Christian. The Apenes family was upper-middle class - their father was a shipping agent with some degree of solvency. Ola's brother would be a noted judge who became involved in politics near the end of the 1930s.

In 1916 Ola finished high school and decided to study engineering, supported by the Swedish company ASEA. In 1921 he joined the military and in 1922 he worked for the Kings Bay Co. on the island of Spitsbergen. He completed his studies in Zurich in 1923 at the Ergenössische Technische Hochschule, and in 1927 he was sent to the United States to work on railway electrification for Gibbs \& Hill. In 1929 he went to Mexico to work for the Swedish telephone company Ericsson. This company was established in Mexico in 1905, and in the 1920 it was the second most important telephone company in the country.102

The first years Ola Apenes spent in Mexico were not entirely satisfactory. In letters that he wrote to his mother Kitty, he often complained about the character and follies of Mexicans. ${ }^{103}$ When he first came to Mexico, he spent several months in the state of Chihuahua, where he felt nostalgic and lonely; this caused him to return to the capital, where he settled permanently.

During the late 1920s and early 1930s, Mexico City had just over a million inhabitants, and in 1928 it gave up its municipal government system. ${ }^{104}$ In addition to some very tangible consequences of the economic crisis of 1929, such as certain shortages and a particular restriction on the circulation of currency, the city in those years experienced very intense political turmoil. The presidential succession in 1929 - in which Pascual Ortiz Rubio, official candidate of the newly formed National Revolutionary Party, ran against José Vasconcelos, the opposition candidate - aroused emotions in the political world, the intellectual environment, and the various social sectors at the beginning of the 1930 s. $^{105}$ The Cristero War had come to an unconvincing end by

idea of the archaeological discoveries, photographs, and films that Ola Apenes made in Mexico. It also mentions his relationship with Frances Gillmor and his early death. It is a wonderful introduction to the life and work of this little-known Norwegian. In this section, I wish to emphasize only his activity as an archaeologist and humanist, and his contributions to the knowledge of indigenous pre-Hispanic Mexico.

102 Gabriel Székely Ericsson en el tercer milenio (México: Editorial Planeta-Ericsson, 200o), 126-131.

103 Lars Lervik Langås, Ola Apenes. En norsk migrants forhold til Mexico, 1929-1943 (University of Oslo, 2012), 31-35.

104 Ariel Rodríguez Kuri, "Ciudad oficial 1930-1970" in Historia política de la Ciudad de México (Desde su fundación hasta el año 20oo), ed. Ariel Rodríguez Kuri (México: El Colegio de México, 2012), 423.

105 John Skirius, José Vasconcelos y la cruzada de 1929 (México: Siglo XXI Editores, 1978). 
establishing the modus vivendi between the hierarchy of the Catholic Church and the postrevolutionary government, then led by Emilio Portes Gil. He was serving as interim president following the assassination of president-elect General Álvaro Obregón in July 1928. The iron hand of former president Plutarco Elías Calles, top leader of the Mexican Revolution, was felt to such an extent that the period from 1928 to 1934 was called "El Maximato."106

That era was characterized by a continuous political crisis and the main scenario was Mexico City. An exacerbated nationalism came up against the cosmopolitan pretentions of the intellectual elites, and a vigorous stream of self-awareness and self-discovery of what it meant to be Mexican at that time and throughout history, took place in the academic and cultural circles of the Mexican capital. ${ }^{107}$ Art and literature, as well as historical, sociological, archaeological, and anthropological research were especially oriented toward the indigenous and pre-Hispanic Mexico. ${ }^{108}$ Ola Apenes arrived in this environment plagued by street fighting, administrative restructuring, and conflicts between Mexican nationalists and cosmopolitans bolstered by much foreign scrutiny.

While he integrated with relative ease into the activities of the Ericsson company, in his free time he became particularly interested in Mexican archaeology and ancient Mexican history. He developed a special interest in photography and iconography of both pre-Hispanic ruins and the contemporary indigenous. He also took advantage of the opportunity to write about Mexico as a correspondent for the Norwegian newspaper Aftenposten. ${ }^{109}$

In the early 1930s, he joined the research being done then on pre-Hispanic topics under the direction of Mexican scholars Alfonso Caso and Rafael García Granados. Between 1930 and 1933, he attended classes on pre-Hispanic culture and archaeology at the National Autonomous University of Mexico (UNAM). At first, he was most taken by the Maya culture. His vocation for mathematics and his new interest in pre-Hispanic archaeology led him to work on the Maya

106 John W.F. Dulles, Ayer en México. Una crónica de la Revolución (1919-1936)(México: Fondo de Cultura Económica, 1977).

107 Henry C. Scmidt, The Roots of Lo Mexicano. Self and Society in Mexican Thought, 1900-1934 (College Station: Texas A\&M University Press, 1978) and Ricardo Pérez Montfort, Avatares del nacionalismo cultural. Cinco ensayos (México: CIESAS-CIDEHM, 200o).

108 Mary Kay Vaughan and Stephen E. Lewis, eds., The Eagle and the Virgin: Nation and Cultural Revolution in Mexico (Durham: Duke University Press, 2006) and Ricardo Pérez Montfort, Estampas de nacionalismo popular mexicano. Diez ansayos sobre cultura populary nacionalismo 2nd ed.(México: CIESAS-CIDEHM, 2003).

109 Lars Lervik Langås, Ola Apenes. En norsk migrants forhold til Mexico, 1929-1943 (University of Oslo, 2012), 31-35. 
and Aztec calendars. He was, along with Alfonso Caso, one of the first academics to publish articles that related these calendars with the Gregorian and Western ones. ${ }^{110}$ However, his interests in archaeological subjects were quite varied. According to Pablo Martínez del Río, every Sunday he went on expeditions around Mexico City, and he soon became a specialist in the areas of the ancient shores of Lake Texcoco, from Chimalhuacán to Xochimilco. ${ }^{111}$

Together with other Scandinavians, such as Sigvald Linné, Holger Graffman, Helga Larsen, and the young Bodil Christensen, he wanted to make known, both in Northern Europe and in the United States, a wide variety of topics relatively unpublished in scholarly and popular publications. ${ }^{112}$ Like his colleagues, Apenes also wrote articles about archaeology, ethnography, and even simple folkloric descriptions, often accompanied with his own photographs and graphics. ${ }^{113}$ A notable example was the article "The Pond in Our Backyard," which was published in the magazine Mexican Life in March $1943 .{ }^{114}$ In this piece, Apenes admitted that it was very difficult to acknowledge at first glance the existence of the huge lake that was once part of the Valley of Mexico. After describing how he began to recognize its existence by way of some old maps and to discover some of the lake-based practices that could still be found in the towns surrounding the capital, such as catching fish and birds or collecting salt and tequesquite (a natural mineral salt), Apenes concluded that "what is still left of the once great Lake of Texcoco is likely to vanish in the course of a few more years." He therefore called the readers' attention to how close this "pond

110 Ola Apenes, "Tabla de lectura para el cálculo de fechas mayas" in Revista Mexicana de Estudios Antropológicos Volume III, No. 1 (January-April 1939) and "Tabla de cálculo y correlación del calendario mexicano" in Revista Mexicana de Estudios Antropológicos Volume III, No. 3 (September-December 1939). Variations of the first of these articles had already been published in the magazine Ethnos of the State Ethnographic Museum in Stockholm, Sweden. See Ola Apenes, "Possible derivation of the 260 day period of the Maya Calendar" Ethnos 1 (1936); "Abbreviated Method for calculating Maya calendar dates" in Ethnos 1 (1937) and "Table for determination of Maya Calendar Round positions" Ethnos 4 (1937).

111 Ola Apenes, Mapas Antiguos del Valle de México, prologue by Rafael García Granados and biographical note by Pablo Martínez del Río (México: UNAM, 1947).

112 See for example Sigvald Linné, Archeological Researches in Teotihuacán, Mexico (Tuscaloosa, University of Alabama Press, 2003), Helga Larsen, "The Mexican Flying Pole Dance" in National Geographic Magazine, Vol. LXXI-3, (March 1937), 387-400 or Bodil Christensen, "The Acatalxqui Dance of Mexico" Ethnos vol. 2,iss. 4 (1937) published by Statens Etnografiska Museum, Stockholm, Sweden.

113 An important collection of his photographs are found in the Linné Archive at the Ethnography Museum of Sweden in Stockholm.

114 Ola Apenes "The Pond in Our Backyard" in Mexican Life XIX No. 3 (March 1943). 
in our backyard" once was. ${ }^{115}$ This article also had extraordinary photographs of the catching of birds and insects, as well as a very well-kept reproduction of an ancient map attributed to Alonso de la Santa Cruz.

Another article on a similar topic was published in Ethnos Magazine shortly after his death. It was about the production of salt in Lake Texcoco. Boasting specific knowledge of Nahuatl, Apenes described the primitive ways in which the iztatleros collected salt water from the lake, which was evaporated to produce the crystallization of its residues through solar heating or in an adobe oven. The article was accompanied by three magnificent photos taken by Apenes himself. ${ }^{116}$ Thus, the Norwegian engineer demonstrated that he was not only a particularly capable ethnographer, but a generator of specific knowledge, who was convinced of the need to disclose it.

These interests not only brought him closer to his Scandinavian colleagues, but also to several Mexican specialists in addition to his already well-known teachers, Alfonso Caso and Rafael García Granados. During his academic and communication activities, Apenes met Manuel Gamio and Miguel Othón de Mendizábal, two essential figures of Mexican anthropology; Pablo Martínez del Río and Wigberto Giménez Moreno, both historians and archaeologists; and some Maya specialists, such as Alfonso Villa Rojas, or experts in Oaxacan and Toltec cultures, such as Jorge Ruffier Acosta. Among themselves, they considered each other as colleagues or collaborators, and in 1937, with the creation of the Anthropological Society of Mexico, Ola Apenes was one of its founding members. ${ }^{117}$ From that moment, his activity as an archaeologist and ethnographer intensified to the point of promoting excavations that he financed at the sites of El Tepalcate, not far from Chimalhuacán, and in Teplaoxtoc, which he described as "a miniature Xochicalco," while he launched the initiative to create a museum about Lake Texcoco in Chimalhuacán. Some of his discoveries and initiatives appeared in the journal American Antiquity in an article titled "The 'Tlateles' of Lake Texcoco," which was not published until after his death in $1943 .{ }^{118}$

115 Ibid, 60 .

116 Ola Apenes, "The primitive salt production of Lake Texcoco, Mexico" in Ethnos IX (1944), $35-40$.

117 Pablo Martínez del Río "Nota biográfica" in Ola Apenes, Mapas Antiguos del Valle de México (México: unAm, 1947). Eusebio Dávalos Hurtado, "La Sociedad Mexicana de Antropología y la v Reunión de Mesa Redonda" in Boletín Bibliográfico de Antropología Americana, 14, no. 1 (1951).

118 Ola Apenes "The 'Tlateles' of Lake Texcoco" in American Antiquity 9, no 1. (July 1943), $29-32$. Xochicalco is a spacious arquelogical site located in the state of Morelos. It is considered one of the most imprortant strategic and commmercial centers of pre-hispanc Mexico. 
But going back to his stay in Mexico during the second half of the 1930s, Apenes also worked with folklorist and author Frances Gillmor from the University of Arizona, with whom he maintained a very close relationship. Apenes met her in Alfonso Caso's class during the mid-1930s. Gillmor had done research on the Navajo Indians in Arizona and New Mexico. She fell in love with Ola and went back to Mexico every summer to attend the National School of Anthropology and History and the National Autonomous University of Mexico (UNAM). Frances and Ola traveled together on the outskirts of Mexico City and to other regions of the country. Frances appears in several of Ola's photographs as a very attractive young woman in the middle of the desert landscape, among huizache trees, and even seated on the huge statue of Tláloc of Cuauhtinchan. Without a doubt, during the time they spent in Mexico, their love - not only for pre-Hispanic and ethnic Mexico but for each other - was more than evident.

If Gillmor mixed her knowledge of Mexican history and folklore with a particular literary intensity, the link between the Norwegian and the American remained to such an extent that in several of Gillmor's works she mentioned him as a careful reader and an enthusiast of her literature. ${ }^{119}$ At least two of Gillmor's books were illustrated by Apenes, which unfortunately were also not published until after his death. ${ }^{120}$ She referred to him in one of her texts as "the closest friend I ever had," and she was the one who sadly notified Apenes's family about his early death. ${ }^{121}$

But during the 1930s, Apenes also worked directly with Ricardo García Granados and with Charles E. Dibble from the University of Utah in the search for Mesoamerican and colonial literary and historiographical sources in order to collect old maps of the Valley of Mexico. In 1947, the UNAM published his posthumous work Mapas Antiguos del Valle de México, which he annotated and identified with particular accuracy. Rafael García Granados wrote the prologue to this edition and emphasized the keenness of Apenes's research. In his introduction, Apenes confirmed that the study of the Valley of Mexico was important to many areas of knowledge: geology, archaeology, history, biology, ethnology, and folklore. He had befriended the director of the General Archive of the Nation, Rafael López; the director of the National Library, José

119 Frances Gillmor, Flute of the Smoking Mirror (Albuquerque: University of New Mexico Press, 1949), vi.

120 See also Frances Gillmor, The King Danced in the Market Place (Phoenix: University of Arizona Press, 1964).

121 Sharon Whitehill, Frances Gillmor, Aztec and Navajo Folclorist (Lewiston, NY: Edwin Mellen Press, 2005). 
Vasconcelos; and the young Antonio Pompa y Pompa, then secretary general of the National Academy of Sciences. Apenes obtained the collection of maps that were part of this publication partly through his research of different international collections. However, he also found them in private collections in Mexico, like those of José Porrúa and Guillermo M. Echarriz. He also acknowledged in the prologue that this work had been linked to Mexican academics and artists like Jorge Enciso, Edmundo O'Gorman, and Santos Balmori. Mapas Antiguos del Valle de México was initially promoted by the rector of the UNAM at that time, Rodulfo Brito Foucher, afterwards by Apenes's teacher, Alfonso Caso, and then by Salvador Zubirán, both rectors of the UNAM as well. It was another one of Ola Apenes's works that was published after his death. ${ }^{122}$

In 1942 the developments in Norway caused by World War II forced him out of Mexico. In the prologue to that posthumous book, Rafael García Granados wrote:

Ola Apenes did not live peacefully in Mexico. It tormented him to think that while he was not in need of anything, his mother back in Norway lacked even the most indispensable things and suffered humiliations by the German invaders. ${ }^{123}$

Apenes therefore decided to join the Norwegian Armed Forces in exile that were concentrating in Canada, and in April of 1943, an acute appendicitis ended his life, before he could even reach the front.

His work, however, left a legacy of singular importance for the archaeological and historical knowledge of both the Valley of Mexico and Lake Texcoco, and of the pre-Hispanic world in general. Ola Apenes was another Norwegian whose presence in Mexico not only had an impact on himself as a person and on his spirit, but also left an indelible mark in this country that still can be unquestionably confirmed in some areas that do not necessarily appear to the naked eye.

The quality, commitment, and passion implicit in the work of Ola Apenes, as well as in the compositions of Halfdan Jebe and the writings of Per Imerslund, have remained as testimony not only of the Norwegian presence in Mexico, but also of the impact that Mexican history and culture had on these three Norwegians who, while contemporaries, were at the same time so divergent and unique.

122 Ola Apenes, Mapas Antiguos del Valle de México (México: unAm, 1947).

123 Ibid., 5 
In these three migrant's journeys from the homeland to an unknown land, the individual experience provided key elements for understanding these processes. Imerslund's, Jebe's and Apenes' involvement and exposure to postrevolutionary Mexico became not only a personal transformation, but it also meant a specific contribution to the arts and knowledge of their time. While Imerslund's writings caught more attention in the European public, specially in Germany and Norway; Jebe's music and Apenes' research had much more influence in Mexican and Yucatecan circles.

Generally, a migrant travels from a known area to one that is unknown, which may involve adventure and discovery, although not always in a conscious manner. But migration also poses a voyage within the very person, a trip that impacts both the individual and the space that he creates in the locale to which he arrives. Thus, the description and the analysis of the processes of interpretation, representation, and learning that is provided by travel from one place to another - particularly from Norway to Mexico, both in geographical and spiritual terms - end up being extremely significant.

The rather unknown experiences that these three travelers represent in post-revolutionary Mexico can be considered as part of a fundamental contribution of this Norwegian migration to the Americas in the first half of the twentieth century. 